\title{
The Natural Remarkable Monuments Create by Geodinamical Processes (Basin Rioni, Georgia)
}

\author{
Giorgi Dvalashvili ${ }^{1}$, Liana Khandolishvili ${ }^{1}$, Salome Tabatadze ${ }^{1}$ and Meri Gugeshashvili ${ }^{2}$ \\ 1. Exact and natural sciences faculty, Ivane Javakhishvili Tbilisi State University, Georgia \\ 2. Vakhushti Bagrationi Institute of Geography, Ivane Javakhishvili Tbilisi State University, Georgia
}

\begin{abstract}
This interest, first of all, was a result of Georgia's unique natural conditions with its mountainous sights or the sea, diverse herbs, animals, different traditions from people living in different corners of the country, agriculture and historical-architectural monuments. By the final stage of the Soviet Union Georgia had a well-developed tourist-resort infrastructure; there were tens of particularly important resorts centers and several hundreds of tourist headquarters. Hundreds of thousands of astonished foreigners or soviet tourists used to visit country every year. They had an opportunity to enjoy pleasantness of each natural area from subtropics of the Black Sea to glaciers of the Caucasus, from Kolkheti Valley to Alazani Valley, Darially Valley to Vardzia—all the tourist routes were filled of natural sights or historical monuments. In 2015 the faculty of Natural Sciences of Ivane Javakhishvili State University conducted a research—Research and Popularization of Natural Monuments of Endogenous Origin in River Rioni Basin EN/15/2015. During research it was revealed very interesting and unique naturally remarkable places, which have a great potential of consumption allowing regions to develop tourist potential. Within frames of the project it was possible to search unique forms of relief, visit and evaluate on spot; in case of necessity include specialists for conducting further ground researches. Recommendations were made to grant status of natural monument to these forms. Meetings were held with the local population in order to notify them importance of the objects within their region and reveal new and unknown places which can be studied in the future.
\end{abstract}

Key words: Caves, waterfalls, canyons, columns, lakes, vaucluse.

\section{Introduction}

Georgia's geomorphological objects have not been researched besides many years of scientists' studies. There are numerous unstudied objects. Finding them, researching them and putting them in order, also listing them on the tourist routes will significantly increase country's tourist industry potential and will attract more local and foreign visitors [1].

In 1982 it was issued Georgia's Red Book in a quite high quality and it really differed from the same sort of books, because along with the endangered species of flora and fauna there were described 77 unique monuments of Georgian nature as protected objects: caves, waterfalls, canyons, columns, lakes, vaucluse, lava flows, etc.

Researching and studying nature monuments is too

Corresponding author: Giorgi Dvalashvili, assistant professor. important for popularizing them in Georgia. Rioni basin is particularly important, as there are unique forms of natural relief altogether. However only scientific groups are aware of them and part of them do not even have a status of natural monuments, but putting them on the list of tourist routes would be interesting for Georgian and foreigner visitors.

Development of tourist infrastructure grants quite high income to any country, no matter how simple is their natural-historical basis is. Countries, which stand on higher economic and social level, always develop this sector, because they believe that if a tourist is satisfied of what they have seen in this country, may get back as an investor or at least popularize their society in homeland so that the others could visit this country as well.

Restoration of Georgia's tourist-resort industry is vital for improving people's social condition, economy and for reinforcing country's political image. 
Tourist routes should include wonders of nature together with historical, architectural, archeology monuments, which will make travelling in Georgia more attractive for foreigners as well as local population.

\section{Materials and Methods}

Municipalities of River Rioni basin are rich of different forms of natural origins. It is possible to discover unknown objects and study them, as only local population might be aware of them. Municipalities include Oni, Ambrolauri, Tsageri, Lentekhi, Kharagauli, Sachkhere, Chiatura, Zestaponi, Terjola, Tkibuli, Tskaltubo, Khoni, Samtrderia, Vani, Baghdati, Martvili, Senaki, Abasha, Khobi and Poti.

Basin of River Rioni is signified by the number of reliefs having endogenous origins and with their diversity as well. However society is not aware of majority of them. Considering the fact that their importance is often unknown, these objects are unconsciously damaged or even destroyed.

Some of the natural monuments or objects are significant and important from international point of view; however those monuments often lose natural beauty as result of harsh interference of humans. In order to avoid this it is necessary that they had a status of natural monument.

Rioni is one of the greatest rivers of Georgia. It takes the reins in Racha, on the slopes of Pasi Mountains. It runs through Racha-Lechkhumi, through Kutaisi and central part of Kolkheti Valley: it separates Kolkheti valley into two and merges with the Black Sea near the City of Poti. It has diverse and spectacular natural conditions. It unites almost every landscape zones from humid subtropics to alpine meadows [2].

The length of River Rioni is $327 \mathrm{~km}$ and the area of the basin is 13,400 cubic kilometers. It starts from Pasa Mountain (South Part of Caucasus), 2,960 meters from the sea level and joins Black Sea near Poti.
The river runs from the mountains to the village Goli via large and deep valley to the South East before merging with the river Zopkhituri. It develops large grove and is branching. It flows through narrow valley to the South West developing a narrow grove. Turns near Oni to the west and runs to the village Alpana. Valley is deep and large here. It has large grove, which is almost entirely flooded during the spring time floods. The river branches and creates islands. There are terraces with the height from 2-3 meters to 20-35 meters, length is $2-3 \mathrm{~km}$ and the width is several hundreds of meters. Villages lie on terraces with gardens and vineyards. Valley is narrow here and there creating gate of rocks (Khidikari). Rioni boldly turns near village Alpana to the South and runs through narrow valley. It becomes large only occasionally and branches. Near a village Tvishi it creates again the gate of rocks. It flows on a Kolkheti valley near Kutaisi, has a large grove, branches and creates isles.

Major affluents of Rioni are Sakaura, Lukhuni, Riseula, Lajanuri, Gubistskali, Tskhenistskali, Tekhuri, Tsivi from the right; Chanchakhi, Gharula, Jejora, Ledikhari, Kvirila, Khanistskali, Sulori, Kumuri and Khevistskali from the left.

Complicated geological and tectonic constitution, characters of erosive and accumulative processes as well as modern vertical movement of the relief results existence of exceptional morphological units: a valley of Rioni in a cave of Mounatain of Racha; afterwards Rioni crosses Shoda-Kedela mountain ringe; from village Nakieti to the village Khvardia Rioni valley spreads in the Racha antrum, which is separated by Tsesi-Kgidikari jaws into Zemo and Kvemo Racha antrums.

We consider Rioni valley within 300-400 meters height from the bed below Oni, because this area clearly reflects morphological picture of the valley and it is resulted by the erosive actions of a River Rioni. 


\section{Results and Discussion}

Basin of River Rioni is tectonically tense region. Lower Jurassic sediments of Mountain Racha are separated from Caucasus's axial crystalline precipitation by deep fault liens. Live rupture line which goes among cretaceous and Jurassic sediments in the south separates the cavernous into two. The bottom of the valley above Shkhilori is wide. Intensive accumulation (10-15 cm a year) and lateral erosion continue into entire Pleistocene and Holocene. The thickness of alluvial deposits is 50-60 meters. Bed drop is $10-15$ meters a kilometer. Lower to the ground Shkhilori there are active erosive processes developed on the bottom of the valleys of rivers Rioni and Chanchakhi. Bed drop is 40-60 meters a kilometer. There are four terraces among brill area. There are terraces below and lower from the grove. On the bottom of the valley there is developed powerful talus cones. On the plateaus of the valley there are active, powerful, mudflow basins which often block River Rioni and cause floods. Active mudflow basins are Gadareula, Khmaura, Gizheshuri, Didghele, Shkhilori, Mukhameshi, Dghviora and others. Among tributaries of Rioni there are River Zopkhitura, Chveshura and Chanchakhi valleys. All of them are U-shaped valleys because of erosion. Old glaciers Zopkhito and Kintrisho used to go over the bottom of River Rioni valley. Moraine layers are indication to this. Village Ghebi is constructed on an area of glacier. Valley of a river Chanchakhi is a U-shaped valley because of active erosive processes. Powerful tongue of Buba-boko glacier used to be about 1,050 meters of height and it was morphologically branched glacier [3].

Both wings of Racha's syncline are segregated by erosive processes. Major rivers are Ritseuli, Askistskali, Shareula, Krikhula. They run from Lechkhumi and Racha ridges and perpendicularly cross the winds of syncline. Valleys are narrow and deep in porphyrite areas vise $\mathrm{V}$ shape. Limestone built sections are mostly canyons, for example canyons of
Kldekari, Kldisubani and Shareula. Depth of erosive sliding is 300-500 meters.

Valley of river Rioni among Alpana and Ghvardia slides into cretaceous limestone. Rioni valley separates Khvamli massive and Labechini hill from each other, as well as western end of Racha plateau. The valley slides deep into limestone (200-500 meters). The valley has a form of canyon on the section of Tvishi and Alpana-Ghardia. There is developed a gravity-block landslide on the right side of the valley near village Sairme and in the upper part there is a breathtaking rock-columns of Sairme.

In the process of recreation of the relief major one among the external dynamic factors there is erosion-accumulative effect of the running water. Frequent and abundant rivers played decisive role for the depth and frequency of relief segregation. Great depth and number of relict (dry) and active (watery) valleys are related to the old and new river chains, as well as existence of erosive valleys, beds, isles, terraces, watersheds and others, which practically determines plasticity of Imereti's relief. Moreover, there is morphogenetic spectrum of underground waters, which is reflected in landslide and karst processes. Their intensity is determined by abundant precipitation, soluble (carbonate) rock, surface slope, anthropogenic actions, etc. Swamp accumulation is related to swamps and creation of appropriate relief forms. Temporary debris flows result to form a talus fan materials. Their old and new formations swirly runs along Khvamli and Racha ridge of $65 \mathrm{~km}$ long south ridges and are very interesting form of morpho-sculptures. The valley of Rion-Tskhenistskal-Kvirila (Imereti) is created by accumulative processes of running waters. Alluvial beds of the rivers, isles, groves, alluvial terraces are frequent in Imereti. Accumulative actions of old and new temporary flows result numerous talus cones (both new and active, as well as old and conserved). They create valleys and nano or micro forms above ridges of mountains and they determine convex profiles of the ridges. Powerful paleo talus cons are forms of mezzo 
relief of Rion-Tskhenistskali and Kvirila. Their surfaces are entirely settled and consumed in people's industry. Considering the above mentioned conditions it is necessary to consider hydrographic network character on Imereti territory, as an important factor of geo-morphogenesis [4].

\section{Conclusions}

Modern relief of River Rioni basin is created as result of long, permanent interaction of endogenous and exogenous processes, permanent interaction. We studied and characterized 12 geo-morphological complexes: tectonic, petrogenic, volcanic, erosive, pluvio-accumulative, river terraces, straightened surfaces, casto, paleo-glacieric, exo-tectonic, forms of reliefs resulted by depletion processes and anthropogenic reliefs. Some of the natural monuments are locally or internationally important, but very often those monuments go through anthropogenesis and very often as result of human interference they lose natural beauty. This is why it is important that those phenomenas had status of natural monument.

Imereti has quite favorable geographic location and has clear natural borders. It is the only region among Georgian regions where there is not official state border. Imereti has diverse and breathtaking natural conditions. There are almost all landscape areas, from humid subtropics to alpine meadows [2].

Among natural monuments we have to mention reserves of Ajameti, Sataplia, national park of Borjom-Kharagauli, as well as castric caves of imereti. It includes Sataplia, Promethe, Navenakhevi, "Tetra" caves, traces of dinosaur in Sataplia. We should also mention thirteen-floor cavernous of Tsutskhvati, which is fascinating just like world-known cavernouses. Speleo-tourism objects are often used for medical treatment for their different micro-climate.

Among the natural monuments there are also column of Katskhi-40 meters of height, limestone column; it is also interesting 30-meters height column in Sairme; Okatse canyon and pleistocene lacustrine sediments of Gorda; natural bridge of Semi; Promethe cave. There is Dzudzuana cabe, where there was discovered 34,000 year-old thread. Among the karstic formations of Georgia there are 180 of them in Imereti. 157 of them are karstic caves, karstic draws and caves are 23. Summing depth of caves is 1,300 meters. Summing length of caves is 41,000 meters. Area of the bottom is 930,000 cubic meters. Area of the cave is 520,000 cubic meters.

Majority of the rivers in the region are perfect of the development of rafting tourism. Among the lakes it should be mentioned Kveda lake formed as result of an earthquake in 1891. The rest of the lakes are smaller and are characterized as karstic and glacier genesis.

Glaciers in the region have a great tourist-recreation potential. It is possible to plan a glacial park at glaciers. Morphometric conditions play particular role in creation of glaciers together with the climate.

The view of the relief, as well as high hypsometric location of glacial forms results perfect conditions for accumulation of snow cover. Larger glaciers are mostly met on central Caucasus. Movement of glaciers is reflected by the existence of glacier stone-rocks. Among them can be mentioned Kvabtatana, Gloli Stone-Rocks; Mglissarbieli Stone-Rock (Datuseli Stone-rock-Ambolauri municipality, $1,800 \mathrm{~m}-20 \times 12 \times 10 \mathrm{~m}$-is among the greatest stone-rocks in the world); Jonouli Stone-rocks.

We should mention Tekenteri karstic dwell-in Tsageri municipality located on the Khvamli massive. It is produced under beech hollow. We can also mention Skhvavi glacier, where there is underground glacier move.

Some of the natural monuments are locally or internationally important, but very often those monuments go through anthropogenesis and very often as result of human interference they lose natural beauty. This is why it is important that those phenomenas had status of natural monument. 
Lots of natural monuments were damaged in Georgia or have been devastated lately. It is necessary to carefully register and protect natural monuments in order to retain natural phenomena. Lots of unique natural monuments are not organized and protected. In case of popularization it is possible to include natural monuments in tourist-resort aims [5].

Studying natural monuments of the region for their popularization is an important issue. Rioni basin is important and rich with different endogenous forms making it possible to discover unknown objects only familiar to local population and research them.

\section{References}

[1] Dvalashvili, G. 2016. Basin of River Rioni (Naturally Remarkable Monuments). TSU Publishing, 294.

[2] Georgia’s Red Book edition "Soviet Georgia.” Tbilisi 1982, 256.

[3] Chkheidze, O. 2003-2005. Imereti Geomophology. Part I, II. Tbilisi, "science".

[4] Kharadze, K. 2014. Georgia's Natural Monuments. Tbilisi, 424.

[5] Matchavariani, L., Kalandadze, B., Lagidze, L., Gokhelashvili, N., Sulkhanishvili, N., Paichadze, N., and Dvalashvili, G. 2015. "Soil Quality Changes in Response to Their Pollution by Heavy Metals, Georgia.” Journal of Environmental Biology 36 (Special issue): 85-90. ISSN: 2394-0379. Journal Home page: www.jeb.co. 